\title{
Analytic Hierarchy Process for Priority Policy on Road Access to Tourist Areas of Berau Regency, East Kalimantan
}

\author{
Rosa Agustaniah \\ Civil Engineering Doctoral Program \\ Brawijaya University \\ Malang, Indonesia \\ rosaagustaniah@yahoo.com
}

\begin{abstract}
Development of favorite tourist destinations in Derawan Island and other places in the southern coastal region of Berau Regency, East Kalimantan, must be supported by the provision of good transportation infrastructure and services to encourage connectivity so that it can increase tourist visits annually. The scale of the priority of access roads to tourist attractions in Berau Regency, East Kalimantan, uses the analytical hierarchy process (AHP) method. The expert data response sample was conducted on 40 respondents in the Road Access Policy to the Tourism Areas of Berau Regency, East Kalimantan consisting of government, practitioners, and academics who were the right people to be used as respondents in determining the weight of the influence of factors, variables, and indicators. Respondents' assessment of several sub-criteria produced priority scale hierarchy weights for level 2 on the highest criteria for road conditions at $57.054 \%$. The weighted land use priority scale is $13,694 \%$ and level 3 sub-criteria in the socio-cultural - tourism sector are $50.8 \%$. The condition of access to transportation networks to the favorite tourist destinations of Derawan Island and the southern coastal region of Berau Regency, East Kalimantan, is still relatively low with a considerable degree of accessibility, plus points of damage that need to be addressed.
\end{abstract}

Keywords: AHP, priority policy

\section{INTRODUCTION}

The national tourism sector is now the most important issues for national development. Foreign exchange contribution and employment in this sector are very significant for the country's foreign exchange. The revenue of foreign exchange from the tourism sector since 2016 has overtaken the income from oil and gas, but it is below the income from CPO. It is estimated that in 2019, the tourism sector will become the main contributor of foreign exchange in Indonesia.

Development of favorite tourism destination in Derawan Island and other places in the southern coastal area of Berau Regency, East Kalimantan (Fig. 1), must be supported by the provision of good transportation infrastructure and service to encourage connectivity so that it can increase tourists visiting annually. This can be seen cumulatively, the number of foreign tourists visit this province in the period January 2017 - April 2018 reaches 5,611 visiting.

Many factors influence potential development of tourism in East Kalimantan, one of that is the problem of

\author{
Achmad Wicaksono \\ Education Development and Quality Assurance (LP3M) \\ Chairman Institute \\ Brawijaya University \\ Malang, Indonesia \\ wicaksono1968@yahoo.com
}

infrastructure related to the accessibility is still an obstacle, where road access to the tourism attractions need to be addressed. Tourists will think again if they want to enjoy the beauty but collide with the problem of facilities that prevent them from going there. The problem faced in traveling in the area of Berau Regency, East Kalimantan is that the road network service is not optimal. The road conditions determine the comfort of road users, the convenience of road users is the responsibility of the relevant agencies and if there is damage to infrastructure on the road it becomes the authority of the agency to preserve it.

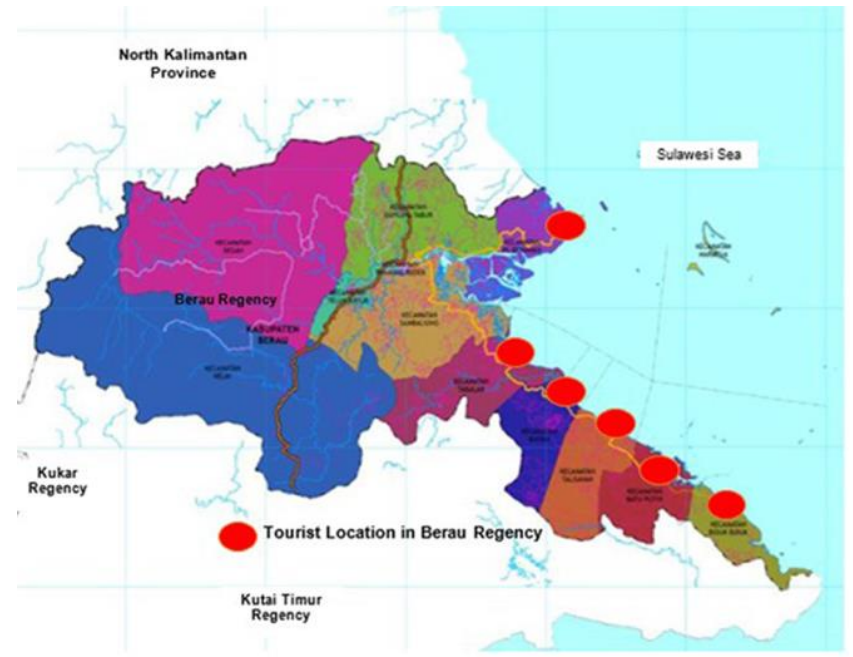

Fig. 1. Map of tourists locations in Berau Regency.

The priority scale of road access to tourism attractions in Berau Regency, East Kalimantan, uses the analytical hierarchy process (AHP) method. The AHP method can be used in solving the problem of decisions to allocate benefits or costs for handling road preserves so that it can carry out planning into the projected future and prioritize handling.

\section{RESEARCH METHOD}

\section{A. Data Collection}

Based on the AHP approach, the respondent who is the resource person for weighting is an expert who has expertise following the research topic (expert response) that is carried out. The expert data response sample was conducted on 40 respondents in the road access policy to the tourism areas of 
- Level II; road priority criteria;

A. Economic factor,

B. Land use factor,

C. Road condition factor,

D. Traffic volume factor, and

E. Policy factor,

- Level III; development of Level II, called subcriteria.

Sub criteria for road conditions, traffic volume, economy are obtained from Decree No.77 of Director General for Highways in 1990 while subcriteria for policy and land use are obtained through interviewing respondents who play a role in government policymaking
A1. Benefit/worthiness
A2. Activity cost
B1. Social - cultural - tourism sector
D1. Light truck
D2. Medium and heavy truck

$\begin{array}{lc}\text { B2. Trade - service } & \text { D4. Four-wheeled car } \\ \text { Bector } & \text { D5. Motorcycle } \\ \text { B3. Agriculture Sector } & \text { E1. District } \\ \text { B4. Education Sector } & \text { Musrenbang } \\ \text { C1. Pothole } & \text { E2. Regency } \\ \text { C2. Depression } & \text { Musrenbang } \\ \text { C3. Cracking } & \text { E3. Province } \\ \text { C4. Rutting } & \text { Musrenbang } \\ \text { C5. Shoulder } & \text { E4. Additional budget } \\ \text { C6. Cross inclination } & \end{array}$
L. Saaty in the 1970s. AHP is a decision-making system using mathematical models. AHP helps in prioritizing several criteria by conducting pairwise comparison analysis of each criterion. AHP is also a flexible model that provides an opportunity for individuals or groups to develop ideas and define problems by making their assumptions and obtaining the desired solutions from them. To support decision-makers that involve their experience, knowledge, and intuition. AHP describes decision problems into elements, according to their general characteristics, and levels, which correspond to the general characteristics of the elements. The top-level is the "focus" problem or final goal; intermediate level according to criteria and sub-criteria, while the lowest level contains "alternative decisions". If each element of each level depends on all elements of the upper level, then the hierarchy is complete; if not, it is defined as incomplete. Elements of each level are compared in pairs concerning specific elements at the top level directly.

\section{ANALYSIS}

AHP method begins with the distribution of the questionnaire to several respondents. It is distributed which is selected by purposive sampling technique, namely "sampling techniques with certain considerations". This technique can be interpreted as a sampling process by determining in advance the number of samples to be taken, then the selection of samples is done based on certain objectives. The numbers given to respondents' perceptions are a comparison scale of each of the criteria and sub-criteria factors. The processes that occur in the AHP method for the priority policy of road access to the Tourism Areas of Berau Regency, East Kalimantan are.

\section{A. Development of AHP Hierarchy}

After the problem is defined, it is necessary to do decomposition which is to break the whole problem into its elements. If you want to get accurate results, solving is also done on the elements until it is impossible to do further solutions so that there are several levels of the problem. For this reason, this analysis process is called a hierarchy. Fig 2, compilation of hierarchical structures consists of 3 (three), namely;

- Level I; the goal is to determine the priority of the road
Fig. 2. Analytic Hierarchy Structure.

\section{B. Comparative Judgement}

This stage is to assess the relative importance of two elements at a certain level concerning the level above. This assessment is the core of AHP because the assessment will affect the priority of the elements. The results of this assessment will look better if presented in the form of a matrix called a pairwise comparison matrix. The usual questions raised in the formulation of interest scales are:

- which elements are more (important/preferred/ and so on) and

- how many times more (important/preferred/ and so on)

To obtain a useful scale when comparing two elements, someone who will provide an answer needs a thorough understanding of the elements that are compared and their relevance to the criteria or objectives to be achieved. In evaluating the relative importance of the two elements, the reciprocal axiom means that if element $i$ is rated 3 times more important than $\mathrm{j}$, then element $\mathrm{j}$ must be equal to $1 / 3$

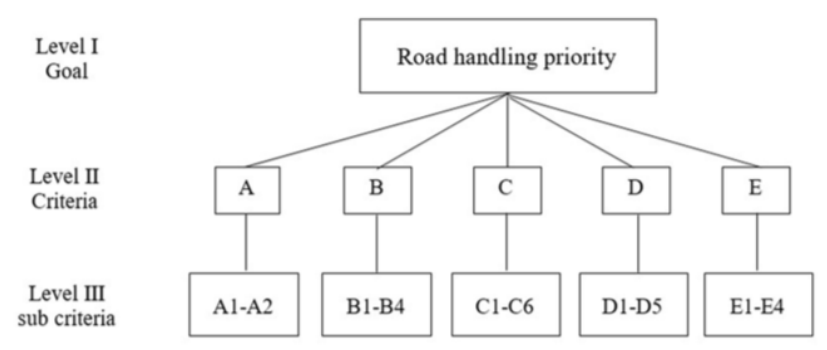


times the importance of the element i. Besides that, the comparison of the same two numbers will result in number 1 , the meaning is equally important. Two different elements can be considered equally important. If there are $\mathrm{n}$ elements, a pairwise comparison matrix of size $\mathrm{n} \times \mathrm{n}$ will be obtained.

The scale of pairwise comparison is based on AHP fundamental values with weighting from value 1 to equally important to 9 for very important following TABLE I, from the arrangement of pairwise comparison matrices several priorities are generated which are the relative effects of several elements on the existing level on. Eigenvector calculations by multiplying the elements in each row and multiplying by the root $n$, where $n$ is an element. Then normalize to bring together the number of columns obtained. By dividing each value by the total value the decision-maker can determine not only the ranking order of priority for each stage of the calculation but also the magnitude of the priority. These criteria are compared based on the opinions of each decision-maker and then their priorities are taken into account.

TABLE I. FORMATION OF THE INITIAL SUB CRITERIA MATRIX

\begin{tabular}{|l|l|l|l|l|l|}
\hline & \multicolumn{1}{|c|}{$\mathbf{A}$} & \multicolumn{1}{c|}{ B } & \multicolumn{1}{c|}{ C } & \multicolumn{1}{c|}{ D } & \multicolumn{1}{c|}{ E } \\
\hline A & 1 & 0.769 & 0.538 & 1.038 & 2.231 \\
\hline B & 1.300 & 1 & 0.538 & 2.154 & 0.654 \\
\hline C & 1.857 & 1.857 & 1 & 1.346 & 0.885 \\
\hline D & 0.963 & 0.464 & 0.743 & 1 & 0.923 \\
\hline E & 0.448 & 1.529 & 1.130 & 1.083 & 1 \\
\hline$\Sigma$ & 5.568 & 5.620 & 3.950 & 6.623 & 5.692 \\
\hline
\end{tabular}

\section{Synthesis of Priority}

Each matrix is pairwise comparison then eigenvector is searched to get the local priority because the pairwise comparison matrix is found at each level, so to get global priority it must be synthesized between local priority. The procedure for synthesizing is different according to the shape of the hierarchy. Ordering elements according to relative importance through a synthesis procedure is called priority setting.

TABLE II. VECTOR EIGENVALUES FOR PRIORITY CRITERIA

\begin{tabular}{|l|l|l|l|l|l|l|l|l|}
\hline & \multicolumn{1}{|c|}{$\mathbf{A}$} & $\mathbf{B}$ & $\mathbf{C}$ & $\mathbf{D}$ & $\mathbf{E}$ & total & wi & $\begin{array}{c}\boldsymbol{E}- \\
\text { Vektor }\end{array}$ \\
\hline $\mathrm{A}$ & 1 & 0.769 & 0.538 & 1.038 & 2.231 & 0.960 & 0.1919 & 0.1333 \\
\hline $\mathrm{B}$ & 1.300 & 1 & 0.538 & 2.154 & 0.654 & 0.986 & 0.1972 & 0.1369 \\
\hline $\mathrm{C}$ & 1.857 & 1.857 & 1 & 1.346 & 0.885 & 4.107 & 0.8214 & 0.5705 \\
\hline $\mathrm{D}$ & 0.963 & 0.464 & 0.743 & 1 & 0.923 & 0.307 & 0.0613 & 0.0426 \\
\hline $\mathrm{E}$ & 0.448 & 1.529 & 1.130 & 1.083 & 1 & 0.840 & 0.1679 & 0.1166 \\
\hline$\sum$ & 5.568 & 5.620 & 3.950 & 6.623 & 5.692 & 7.199 & 1.4397 & 1 \\
\hline
\end{tabular}

Determine the level of importance of the criteria, obtained answers based on the scale/range of assessment. Calculation of element weights is done using a matrix. If in a sub-operating system there are " $n$ " operating elements, namely operating elements $\mathrm{A} 1, \mathrm{~A} 2, \mathrm{~A} 3, \ldots \mathrm{A} n$, then the results of pairwise comparisons of these elements will form a comparison matrix. Pairwise comparisons start at the highest hierarchy level, where a criterion is used as the basis for making comparisons. The form of the pairwise comparison matrix weighs the elements as shown in TABLE II.

The maximum eigenvalue matrix is obtained from the initial matrix multiplied by the E-Vector of each matrix and then the multiplication result is added. This is shown in the following matrix (TABLE III);

TABLE III. MATRIX

\begin{tabular}{|c|c|c|c|c|c|c|c|c|c|}
\hline & $\mathbf{A}$ & B & $\mathbf{C}$ & D & $\mathbf{E}$ & \multirow{7}{*}{$\mathrm{X}$} & $\begin{array}{c}\text { E- } \\
\text { Vektor }\end{array}$ & \multirow{7}{*}{$=$} & \\
\hline $\mathrm{A}$ & 1 & 0.769 & 0.538 & 1.038 & 2.231 & & 0.1333 & & 0.850 \\
\hline $\mathrm{B}$ & 1.300 & 1 & 0.538 & 2.154 & 0.654 & & 0.1369 & & 0.785 \\
\hline $\mathrm{C}$ & 1.857 & 1.857 & 1 & 1.346 & 0.885 & & 0.5705 & & 1.233 \\
\hline $\mathrm{D}$ & 0.963 & 0.464 & 0.743 & 1 & 0.923 & & 0.0426 & & 0.766 \\
\hline $\mathrm{E}$ & 0.448 & 1.529 & 1.130 & 1.083 & 1 & & 0.1166 & & 1.077 \\
\hline$\sum$ & 5.568 & 5.620 & 3.950 & 6.623 & 5.692 & & 1 & & 0.850 \\
\hline & & & & & & & $\lambda_{\max }$ & $=$ & 4.712 \\
\hline
\end{tabular}

\section{Logical Consistency Hierarchy}

Logical consistency states a measure of the consistency of an assessment or weighting pairwise comparison. This test is needed because in actual circumstances there will be some deviations from the relationship so that the matrix is not perfectly consistent. This can occur because of inconsistency in one's preferences.

The hierarchy is the easiest tool for understanding complex problems where the problem is described in the elements concerned, arranging these elements hierarchically and finally evaluating those elements while determining which decisions will be taken. The process of compiling hierarchical elements includes grouping elements in components that are homogeneous in nature and compiling these components at the appropriate level of the hierarchy. Hierarchy is also a system with multiple levels of decision with several decision elements at each level of decision.

\section{TABLE IV. PAIRED COMPARISON MATRIX SCALE}

\begin{tabular}{|l|l|l|}
\hline Interests & \multicolumn{1}{|c|}{ Definition } & \multicolumn{1}{c|}{ Explanation } \\
\hline 1 & $\begin{array}{l}\text { The one element is as important as } \\
\text { the other elements (equal } \\
\text { importance) }\end{array}$ & $\begin{array}{l}\text { Both elements } \\
\text { contribute equally to } \\
\text { that trait }\end{array}$ \\
\hline 3 & $\begin{array}{l}\text { One element is slightly more } \\
\text { important than other elements } \\
\text { (moderate more importance) }\end{array}$ & $\begin{array}{l}\text { Experience states a } \\
\text { little in favor of one } \\
\text { element }\end{array}$ \\
\hline 4 & $\begin{array}{l}\text { One element is more important } \\
\text { than other elements (essential, } \\
\text { more important) }\end{array}$ & $\begin{array}{l}\text { Experience shows a } \\
\text { strong side to one } \\
\text { element }\end{array}$ \\
\hline 7 & $\begin{array}{l}\text { One element is more important } \\
\text { than the other elements } \\
\text { (demonstrated importance) }\end{array}$ & $\begin{array}{l}\text { Experience shows } \\
\text { that it is strongly } \\
\text { liked and dominated } \\
\text { by an invisible } \\
\text { element }\end{array}$ \\
\hline 9 & $\begin{array}{l}\text { The absolute one element is more } \\
\text { important than the other } \\
\text { (absolutely more importance) }\end{array}$ & $\begin{array}{l}\text { Experience shows } \\
\text { that one element is } \\
\text { more important }\end{array}$ \\
\hline $2,4,6,8$ & $\begin{array}{l}\text { When in doubt between two } \\
\text { adjacent values }\end{array}$ & $\begin{array}{l}\text { This value is given } \\
\text { if a compromise is } \\
\text { needed }\end{array}$ \\
\hline
\end{tabular}

To quantify the qualitative opinion, a rating scale is used so that opinion values will be obtained in the form of numbers. According to Saaty (1990), for various problems, a scale of 1 to 9 is the best scale in qualifying opinions, which is based on its accuracy based on the value of Root Mean 
result of the eigenvector of the criteria for the comparison

Square (RMS) and Median Absolute Deviation (MAD). The values and definitions of qualitative opinions on the Saaty comparison scale are in the TABLE IV.

Comparison values of criteria that have been obtained then processed to rank the criteria of all existing criteria, both qualitative criteria and quantitative criteria can be compared following predetermined judgment to produce weights and priorities. If the value is more than 10 percent, the data assessment must be corrected. Deviations from consistency are expressed by $C I$ (consistency index);

$$
C I=\left(\lambda_{\max }-n\right) /(n-1)
$$

with $n$ is the size of the matrix.

Random matrices with rating scales 1-9 along with their opposite as RI (random index) TABLE V. Comparative matrices can be accepted if the value of CR (consistency ratio), less or equal to:

$$
C R=C I / R I
$$

TABLE V. AVERAGE RANDOM MATRIX CONSISTENCY (RI VAlue)

\begin{tabular}{|c|c|c|c|c|c|c|c|}
\hline Matrix size & $\mathbf{1}$ & $\mathbf{2}$ & $\mathbf{3}$ & $\mathbf{4}$ & $\mathbf{5}$ & $\mathbf{6}$ & $\mathbf{7}$ \\
\hline $\begin{array}{l}\text { Random Index } \\
\text { (inconsistency) }\end{array}$ & 0.00 & 0.00 & 0.58 & 0.90 & 1.12 & 1.24 & 1.32 \\
\hline
\end{tabular}

TABLE VI is a ratio consistency value (CR) smaller than 0.1 which means it is smaller than $10 \%$, then the value is following the consistency requirements, which must be less than 0.1 or $10 \%$.

TABLE VI. RECAPITULATION OF RATIO CONSISTENSI (CR)

\begin{tabular}{|l|l|l|}
\hline \multicolumn{1}{|c|}{ Criteria } & \multicolumn{1}{|c|}{$\begin{array}{c}\text { Ratio } \\
\text { Consistency } \\
(\boldsymbol{C R})\end{array}$} & Information \\
\hline Level 2 & $-0.064<0.1$ & consistent \\
\hline Level 3; Sub criteria Economic factor & $-0.329<0.1$ & consistent \\
\hline Level 3; Sub criteria Land use factor & $-0.187<0.1$ & consistent \\
\hline $\begin{array}{l}\text { Level 3; Sub criteria Road condition } \\
\text { factor }\end{array}$ & $0<0.1$ & consistent \\
\hline $\begin{array}{l}\text { Level 3; Sub criteria Traffic volume } \\
\text { factor }\end{array}$ & $-0.247<0.1$ & consistent \\
\hline Level 3; Sub criteria Policy factor & $-0.239<0.1$ & consistent \\
\hline
\end{tabular}

\section{Assessment of RoAd ACCESS PRIORITy POLICE}

By applying the procedure described in the AHP method, the results show the highest importance for criterion $\mathrm{C}$ (Fig. 3), which is the factor of road conditions (57.05\%); This shows that the expert response wants improvement in road transport infrastructure is very important. Roads that have good quality and are easy to pass through will greatly support efforts to accelerate development. Also, good road quality can attract investors, especially from outside, to invest in the tourist areas of Berau Regency. Without the way to have quality, social and economic activities of the community will be hampered resulting in the region will be difficult to develop. As a matrix in TABLE V, the component gives an estimate of the weighting criteria. The main eigenvalue of this matrix is $\lambda_{\max }$ $=4.712$, with a consistency ratio of $C R=0.1<0.1$ the results are consistent.

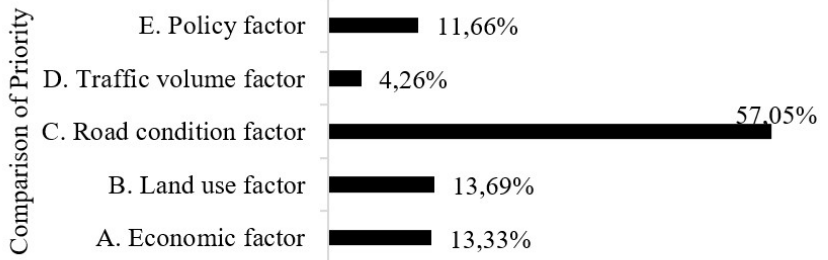

estimate of the weighting criteria

Fig. 3. Comparison of Priority on Road Handling Factors.

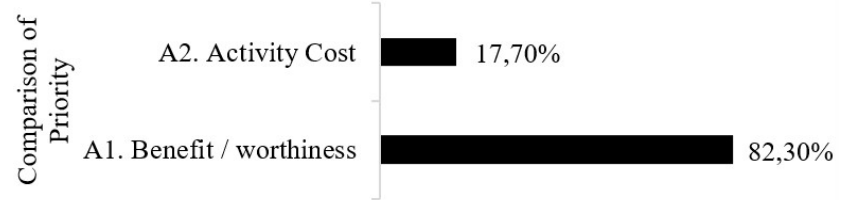

estimate of the weighting criteria

Fig. 4. Comparison of Priority on Economic Factors.

Fig. 4, produces a comparison between Benefit/ worthiness $(82.3 \%)$ and activity costs (17.70\%). This identifies that the benefits of prioritizing road access to the tourist areas of East Kalimantan's Berau Regency can be direct benefits and indirect benefits. Direct benefits are benefits that can be felt and can be measured as a result of investment. The benefits that are included or taken into account in the analysis are the benefits that can be calculated/quantified (tangible benefits), while the intangible benefits are included/calculated as benefits that need to be considered in deciding whether or not a project is feasible.

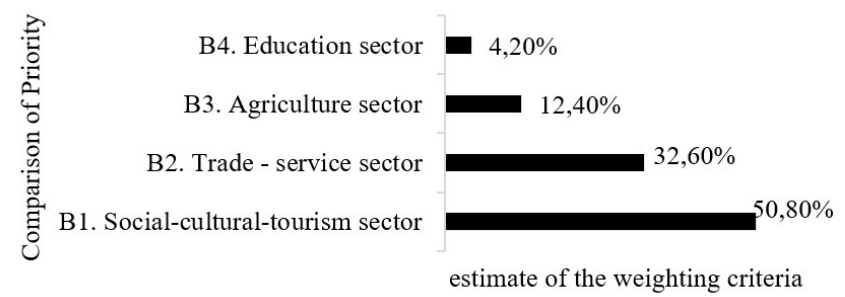

Fig. 5. Comparison of Priority on Land Use Factors.

The development of tourism influences changes in land use and stimulates the growth of new economic activities and new job opportunities, especially in the fields of trade and service providers (Fig. 5). Apart from the economic side, the development of tourism in the tourist area of Berau Regency affects the social conditions of the community. The review of socio-cultural conditions is also associated with changes in existing land use, so that interrelated confirmation will be made between the availability of facilities and socio-cultural activities. Various development of tourism and non-tourism sector facilities are carried out 
to meet the increasing needs of tourists visiting the tourist area of Berau Regency. Construction of facilities in tourist areas causes changes in land use, especially non-built land into built-up land. The tourism sector that appears in tourist areas indirectly affects the socio-economic conditions of local communities.

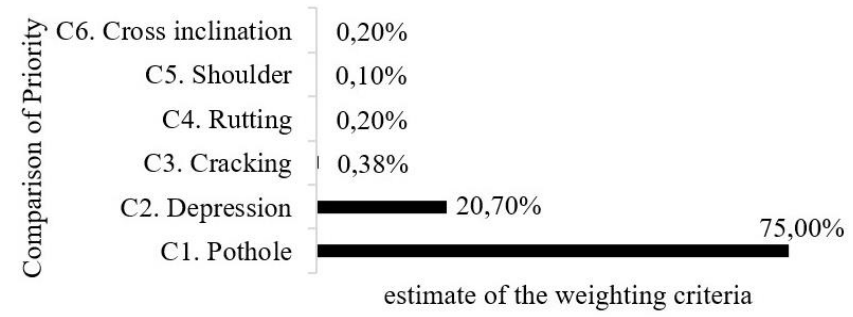

Fig. 6. Comparison of Priority Factors on Road Performance.

Following its characteristics, the road tends to experience a decrease in conditions which is indicated by the occurrence of damage to the pavement. To slow down the rate of deterioration and maintain conditions at a reasonable level, the road needs to be properly maintained so that it can function at all times. The shape and causes of road damage that occur on the road forms are very diverse, ranging from cracking, pothole, corrugation to forming rutting and asphalt puddles on the surface bleeding, Fig. 6.

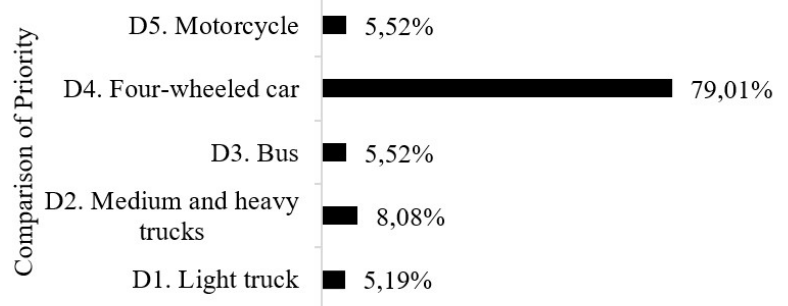

estimate of the weighting criteria

Fig. 7. Comparison of Priority Factors on Traffic Composition.

As a measure of the amount of current, it is used a volume term that indicates the number of vehicles that pass a point in a unit of time. Traffic volume is very useful as a basic consideration for the use of more rigorous planning requirements such as geometric planning, road construction, and road capacity (Fig. 7)

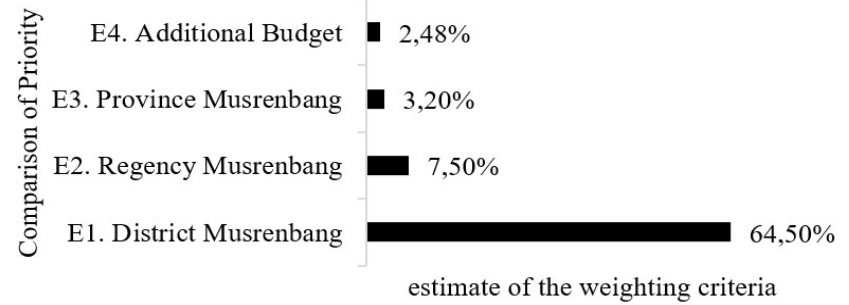

Fig. 8. Comparison of Priority on Policy Factors.

In the development planning meeting (Musrenbang) of East Kalimantan Province, several agreed aspects were agreed for the next five years' work program to be developed in each region in improving the economy and social welfare. The priority aspects in regional development are the development of tourism areas, agriculture and plantations, revitalization of ports, and mining. To support improving the development of regions that are prioritized in regional development, adequate road infrastructure is needed (Fig. 8)

\section{CONCLUSION}

Respondents' assessment of several sub-criteria produced priority scale hierarchy weights for level 2 on the highest criteria for road conditions at $57.054 \%$. The weighted land use priority scale is $13,694 \%$ and level 3 sub-criteria in the socio-cultural - tourism sector are $50.8 \%$. the condition of transportation network access to the favorite tourist destinations of Derawan Island and the southern coastal region of Berau Regency, East Kalimantan, is still relatively low with a considerable degree of accessibility, plus points of damage that need to be addressed. To increase tourism visits to this area, road improvements must be made so that visitors can enjoy tourism comfortably and safely while on the trip. The development of tourism influences changes in land use and stimulates the growth of new economic activities and new job opportunities, especially in the fields of trade and service providers. Apart from the economic side, the development of tourism in the tourist area of Berau Regency affects the social conditions of the community. This shows that the expert response wants improvement in road transport infrastructure is very important. Roads that have good quality and are easy to pass through will greatly support efforts to accelerate development. Besides, good road quality can attract investors, especially from outside, to invest in the tourist areas of Berau Regency.

\section{REFERENCES}

[1] Berau Regency Central Bureau of Statistics, Berau in numbers 2018.

[2] Brohman, J. New directions in tourism for Third World development. Annals of Tourism Research. https://doi.org/10.1016/01607383(95)00043-7. 1996.

[3] Chen, C. L., \& Bau, Y. P. Establishing a multi-criteria evaluation structure for tourist beaches in Taiwan: A foundation for sustainable beach tourism. Ocean and Coastal Management. https://doi.org/10.1016/j.ocecoaman.2015.12.013. 2016.

[4] East Kalimantan Provincial Regulation No 14., concerning the Regional Tourism Development Master Plan of East Kalimantan Province. 2008.

[5] Law of the Republic of Indonesia No 10., Concerning Tourism. 2009.

[6] Oka A. Yoeti. Tours and travel marketing. In PT Perca Jakarta. 2003.

[7] Pedroso, G., Bermann, C., \& Sanches-Pereira, A. Combining the functional unit concept and the analytic hierarchy process method for performance assessment of public transport options. Case Studies on Transport Policy. https://doi.org/10.1016/j.cstp.2018.09.002. 2018.

[8] Presidential Regulation of the Republic of Indonesia No 64., Concerning Strategic Coordination between Tourism Sectors. 2014.

[9] Saaty, T. L. Decision making with the Analytic Hierarchy Process. Scientia Iranica. 2002

[10] SK No. 77 / KPTS / Db / 1990., Technical Guidelines for Planning and Preparation of District Road Programs, Directorate General of Highways, Ministry of Public Works. 1990.

[11] Sugiyono. Qualitative and Quantitative Research Methods and R \& D (in Indonesian). Bandung:Alfabeta. https://doi.org/10.1017/CBO9781107415324.004. 2012.

[12] Tarigan, Robinson., Regional Development Planning. PT Bumi Aksara. Jakarta. 2005.

[13] The Republic of Indonesia Government Regulation No 50., concerning the 2010 - 2025 National Tourism Development Master Plan has been established 222 (two hundred twenty two) National 
Tourism Development Areas (KPPN) in 50 (fifty) National Tourism Destinations (DPN) and 88 (eighty eight) National Tourism Strategic Areas (KSPN). 2011.

[14] Yawson, D. O., Armah, F. A., Okae-Anti, D., Essandoh, P. K., \& Afrifa, E. K. A. Enhancing Spatial Data Accessibility in Ghana: Prioritization of Influencing Factors Using AHP. International Journal of Spatial Data Infrastructures Research. https://doi.org/10.2902/1725-0463.2011.06.art13. 2011. 